\title{
Land Tenure Security and Home Maintenance: Evidence from Japan
}

\author{
Shinichiro Iwata Hisaki Yamaga
}

Working Paper No. 224

September 2007 


\title{
Land tenure security and home maintenance: Evidence from Japan
}

\author{
Shinichiro Iwata \\ Faculty of Economics, University of Toyama
}

Hisaki Yamaga

Graduate School of Systems and Information Engineering, University of Tsukuba September 2007

\begin{abstract}
This paper considers two land tenure modes - leasehold and freehold - and models housing maintenance incentives under land tenure security in Japan. Compared with freeholders, leaseholders are equally likely to remain in the premises, but spend less on home maintenance, because leaseholders are not full residual claimants, even under land tenure security. The empirical results show that maintenance expenditures of leaseholders are about $30 \%$ lower than those of freeholders in the Japanese residential land market. Empirical evidence also indicates that leaseholders are equally likely to remain in their premises even when they undermaintain their dwellings.
\end{abstract}

Keywords Land tenure security $\cdot$ leasehold $\cdot$ freehold $\cdot$ maintenance expenditures

JEL classification $\mathrm{K} 11 \cdot \mathrm{R} 29 \cdot \mathrm{R} 38$ 


\section{Introduction}

Little is known about the relationship between land tenure security and home maintenance in developed countries. Residential land lease is rare in many developed economies because the housing unit and the land are usually treated as a single property (Kanemoto, 1990). ${ }^{1}$ In several parts of developed economies, however, the land is regarded as a separate asset from the housing unit, and, consequently, residential land lease is practiced. ${ }^{2}$ The purpose of this paper is to offer a theoretical model and to empirically test the effect of land tenure security on maintenance expenditure decision in Japan. The paper also examines removal decisions of lessees under land tenure security. To shed light on these problems, the paper compares two land tenure modes - leasehold and freehold. Comparing leasehold with freehold shows us whether decisions of leaseholders are optimal or not, because freeholders achieve optimal decisions. ${ }^{3}$

Both residential land lease contracts and land tenure security have a variety of forms in the world. Japan is a country, however, which shares a common feature with many other countries in the world. Under leasehold, tenants own the home and lease the land beneath it. ${ }^{4}$ Tenants occupy the land under a tenancy for years. ${ }^{5}$ They have to return the land and lose the premises at the expiration of the lease term. It is difficult for landowners to induce responsible behavior by tenants, because tenants are not residual claimants on housing (Kanemoto, 1990; Miceli, Sirmans, and Turnbull, 2001). ${ }^{6}$ Thus, perceived land tenure security is a precondition for tenants to invest in housing improvements (Mayo and Angel, 1993; Payne, 2001). ${ }^{7}$

\footnotetext{
${ }^{1}$ See Asabere (1981, 2004), De Souza (1998), Jimenez (1984), Mayo and Angel (1993), and Payne (2001) for the relation between land tenure system (security) and the property price (investment in housing construction and improvements) in developing countries.

${ }^{2}$ For example, see: Blandy and Robinson (2001) and McDonald (1969) on UK, Fry and Mak (1984) and La Croix, Mak, and Rose (1995) on Hawaii, Hong (1998) on Hong Kong, Janssen (2003) on Stockholm.

${ }^{3}$ Blandy and Robinson (2001) have indicated that the discourse of property law in England and Wales uses the formal legal language of freeholder (an occupier holding 'fee simple absolute in possession') and leaseholder (an occupier holding 'term of years absolute').

${ }^{4}$ The 2006 White Paper on Land and Real Property has stated that there is no equivalent system of leasehold property ownership, there is a property holding system called residential land lease in Japan. In this paper, however, leasehold and residential land lease are treated as the same thing.

${ }^{5}$ This is usually set at more than 50 years, but it is just 30 years in Japan.

${ }^{6}$ Using option-pricing theory, Capozza and Sick (1991) have found that a ground lessee will redevelop sooner and at a lower intensity than would a freeholder.

${ }^{7}$ Dale-Johnson (2001) and Grenadier (2005) have shown that the landowner may structure a lease to induce responsible behavior by the lessee. For example, if (1) a contract includes a lease extension option; (2) a lessee has a residual claim; and (3) a ground lease contains strict provisions concerning improvement, then it diminishes the under(re)development problems of the ground lease.
} 
Kanemoto (1990), however, has shown that inefficient housing investment may occur if tenants are not allowed to sublease the land freely. On the one hand, if tenants remain in the dwelling, even after the end of the contractual term, they receive the benefits of the dwelling. On the other hand, if tenants move out, they do not receive the benefits of housing investment because of the prohibition of subleases.

Land tenure security promotes optimal investment if subleasing is allowed (Kanemoto, 1990). If tenants sublet the dwelling, the sublease rent will reflect housing investment. Thus, tenants fully capture the benefits of investment. Leasehold does not differ from freehold in this case.

Seshimo (2003), however, has argued that overinvestment is generated by land tenure security. In his model, tenants can obtain a compensation of removal when they move out. The compensation of removal is assumed to be higher than the sublease rent set in Kanemoto's model. Thus, the benefits of housing investments by tenants are larger than the first-best case. As a result, their housing investments are excessive. Landlords cannot convert the land use as long as they do not compensate the benefits from overinvestment by tenants. Seshimo (2003), thus, has shown that tenants are more likely to remain in the premises.

In this paper, we consider land tenure security in Japan. Lessees are protected by Japanese Land Lease Law as follows. First, tenants retain the option to renew their contracts, coupled with a market ground rent forced on landowners. Second, tenants have a right of claim that landowners purchase the premises at the market prices when they move.

Freehold is maintained optimally, because freeholders are residual claimants of the premises. In comparing leasehold with freehold, our model includes both the undermaintenance case that is similar to Kanemoto (1990) and the over maintenance case that is similar to Seshimo (2003). ${ }^{8}$ In our model, tenants have a residual claim equivalent to the market price of the improvements when they relocate. Therefore, they care about housing as freeholders. The problem is that the amount of payment is decided by the court. The payment may not reflect the full benefits of housing maintenance expenditures, because a lawsuit in relation to the payment may be time-consuming and costly in Japan (Kanemoto, 1997). This problem discourages maintenance

\footnotetext{
${ }^{8}$ Kanemoto (1990) has examined both new housing investment and additional home maintenance. In the empirical part of the paper, we can only obtain expenses of home maintenance. Thus, we only examine maintenance expenditures in the theoretical part of the paper.
} 
incentives of tenants. On the other hand, tenants retain the option to renew their contracts with a market land rent. The incentive of tenants for maintenance is distorted towards the benefits for continued use, because they cannot capture the full benefits when they move. This problem induces overmaintenance by tenants. The above suggests that if the undermaintenance problem outweighs the overmaintenance problem, then undermaintenance occurs, and vice versa. The mobility of tenants is also considered in the paper. Our results show that there is the case where tenants are equally (more) likely to remain in the premises even when they undermaintain their dwellings. Previous studies have not shown this combination.

Using the 1998 Japanese Housing Demand Survey (JHDS) conducted by the Ministry of Land, Infrastructure, and Transport, we test these theoretical hypotheses empirically. This is the first econometric study to analyze the effects of land tenure security on housing maintenance in Japan using cross-sectional microdata. The JHDS asks households to report maintenance expenditures made in the previous five years, 1993-1998. First, we estimate a maintenance expenditure equation using the observations on leasehold properties and freehold properties. The difference between freehold and leasehold captures the effect of land tenure security, because land tenure security only has an effect on leaseholders. Thus, we use a leasehold dummy variable, with freehold being the reference tenure mode.

The JHDS also gives data on the physical condition of housing units. Because maintenance expenditures and the physical condition of housing units might have a positive correlation, the physical condition might be a proxy for the maintenance expenditure before 1993. Following Gyourko and Linneman (1990), we estimate whether premises are in good condition. Again, the leasehold dummy variable captures the effect of land tenure security.

Lastly, the JHDS does ask householders to report whether or not they will move. We estimate a probit model of households' behavior, whether or not they will remain in the premises, with the leasehold dummy variable.

The empirical results show the following: (i) maintenance expenditures of leaseholders are lower than those of freeholders, (ii) leasehold premises are less likely to be in a sound condition than freehold premises, and (iii) leaseholders are equally likely to remain in the premises as 
freeholders.

The remainder of the paper is organized as follows. In the next section, we present our theoretical model. The data and empirical model are described in the third section, along with the empirical results. The final section summarizes the main conclusions of the paper.

\section{The Model}

Leasehold refers to the right to use a piece of land for a limited period of time. Under leasehold, a tenant leases land from a landowner and constructs a housing unit on the land. Upon the termination of a ground lease, the land and all improvements revert to the landowner.

Consider a two-period model. At the beginning of period 1, a landowner and a tenant make a one-period residential land lease contract. The landlord offers the tenant a fixed ground rent $r_{1}$, and the tenant accepts the offer. These decisions at the beginning of period 1 are given in our model. We assume that the tenant erects a single housing unit on the plot of land, and undertakes maintenance during period 1 to mitigate quality deterioration. Let $m$ be the maintenance expenditures undertaken by the tenant. The tenant derives utility of $v_{1}(m)$, which can be expressed in pecuniary terms, in period 1 . We assume, $m$ has positive effects for the tenant living in the dwelling but at a decreasing rate. Thus, $v_{1 m}>0$, and $v_{1 m m}<0$. The tenancy terminates at the end of period 1.

We assume that the residual value (the resale price) of the housing unit is $p_{2}(m)$. That is, $m$ undertaken in period 1 has spillover effects on thehousing value in period 2. Moreover, additional maintenance expenditures are assumed to be zero in the second period. The maintenance increases $p_{2}(m)$ at a decreasing rate. Thus, $p_{2 m}>0$, and $p_{2 m m}<0$.

The initial tenant benefits from the housing value in period 2 if he or she renews the contract. The tenant derives subjective value of $v_{2}=b\left(p_{2}(m)\right)$, where we assume that $v_{2 m}=b_{p_{2}} \cdot p_{2 m}>0$, and $v_{2 m m}=\left(b_{p_{2}}\right)^{2} \cdot\left(p_{2 m}\right)^{2}+b_{p_{2}} \cdot p_{2 m m}<0$.

The second period land rent $r_{2}$ is a random variable, and both the landowner and the tenant know the probability distribution function of rent $g\left(r_{2}\right)$ over an interval $\left[\begin{array}{ll}0 & \bar{r}_{2}\end{array}\right]$, where $0<\bar{r}_{2}$.

We normalize the reservation utility level to 0 when the tenant moves to another dwelling in 
period 2. Then, the maximum rent that he or she pays for the dwelling while enjoying a utility level of at least 0 can be written as $v_{2}(m)$.

\section{Freehold}

For the benchmark, we first consider freehold. Freehold refers to the fact of owning a piece of land for a period of time that is not limited. Furthermore, no restrictions and limitations are placed on the right of a freeholder to enjoy the property, lease it to others, or sell it (Brueggeman and Fisher, 2006). We examine the case where land and the housing unit are owned by a freeholder who leases both to himself or herself in period 1.

In period 2 , the freeholder continue to dwell in his or her housing if $v_{2}(m)$ is greater than or equal to the opportunity cost of holding property $p_{2}(m)+r_{2}$. Otherwise, the freeholder sells or leases the premises with the land.

Sweeney (1974) has shown that the owners of housing units maintain their housing units at a higher standard because of pride in ownership. That is, an owner values the extra utility from maintenance more than the market, so the marginal benefit of maintenance to an owner exceeds that of the market. Brueggeman and Fisher (2006) argue that buyers composing the market for the property are not willing to pay as much for the owner's improvements as the current owner. Following Brueggeman and Fisher (2006) and Sweeney (1974), we assume that:

$$
\begin{aligned}
v_{2}(m) & >p_{2}(m), \\
v_{2 m} & >p_{2 m} .
\end{aligned}
$$

This assumption ensures the possibility that the freeholder stays in the same premises.

We also assume that:

$$
\exists \check{r}_{2} \in\left[0, \bar{r}_{2}\right] \quad v_{2}(m)<p_{2}(m)+\check{r}_{2} .
$$

This assumption ensures that the freeholder can potentially relocate and sell the dwelling.

The freeholder's choice at the beginning of period 2 can be represented as follows:

$$
\left\{\begin{aligned}
G\left(\hat{r}_{2}\right)=\operatorname{Pr}\left[v_{2}(m) \geq p_{2}(m)+r_{2}\right] & \Rightarrow \text { remain } \\
1-G\left(\hat{r}_{2}\right)=\operatorname{Pr}\left[v_{2}(m)<p_{2}(m)+r_{2}\right] & \Rightarrow \quad \text { move }
\end{aligned}\right.
$$


where $G\left(r_{2}\right)$ is the cumulative distribution function (cdf) of $r_{2}$. Equation (1) implies that the freeholder continues to dwell if $r_{2}$ is less than or equal to $\hat{r}_{2}$, or otherwise he or she resells the property in period 2. We refer to $\hat{r}_{2}$ as the critical value. From Eq. (1), we have:

$$
\hat{r}_{2}=\hat{r}_{2}(m)=v_{2}(m)-p_{2}(m) .
$$

Now, we consider the freeholder's payoff. Assume that the freeholder is risk neutral and has the discount factor, set at unity. Then, from Eq. (1), the payoff function can be written as

$$
v_{1}(m)-m+\int_{0}^{\hat{r}_{2}} v_{2}(m) g\left(r_{2}\right) d r_{2}+\int_{\hat{r}_{2}}^{\bar{r}_{2}}\left[p_{2}(m)+r_{2}\right] g\left(r_{2}\right) d r_{2} .
$$

The solution to Eq. (3) satisfies

$$
v_{1 m}+G\left(\hat{r}_{2}\right) v_{2 m}+\left(1-G\left(\hat{r}_{2}\right)\right) p_{2 m}=1
$$

The equilibrium input level, $m_{F}$, can be found by solving Eq. (4), where the subscript $F$ refers to freehold. ${ }^{9}$

\section{Leasehold}

Next, we consider leasehold. Under a leasehold option, the tenant has to return the land and lose the premises at the expiry of a term's lease. That is, in residential land lease contracts, tenants are not residual claimants on housing. For this reason, tenants, unlike freeholders, do not necessarily care about future asset values, they tend to undermaintain dwellings (Kanemoto, 1990; Miceli, Sirmans, and Turnbull, 2001).

The Land Lease Law in Japan, however, attempts to protect tenants in two ways. First, the Land Lease Law admits that the tenant has a right of claim that the landowner purchases the housing unit at the market price. Thus, when the lease is terminated, landowners must settle the asset price of the housing unit on the rented site. The amount of payment is decided by the court. Let $1 / \lambda$, where $\lambda \geq 1$, denotes the shadow cost of the payment. For example, a lawsuit in relation to the payment may be time-consuming and costly (Kanemoto, 1997). Thus, in this paper, we define the following:

\footnotetext{
${ }^{9}$ The second-order condition for a maximum is assumed to hold throughout the paper.
} 
Definition 1 When the tenant moves to another dwelling, he or she receives the payment $(1 / \lambda) p_{2}$, where $\lambda(\lambda \geq 1)$.

Second, it is almost impossible for a landowner to refuse renewal of a tenancy contract that expires if the tenant want to continue it. Landowners, however, could encourage evictions by increasing rents. Thus, to prevent this, judicial precedents from tenancy suits have established that the rent for an incumbent tenant, called here contract-renewal rent, is not permitted to exceed the rent, called market rent, of similar newly rented sites. Thus, we define the following:

Definition 2 The tenant has an option to renew the contract with the contract-renewal rent $r_{2}$.

Then, the tenant's choice at the beginning of period 2 can be presented as follows:

$$
\left\{\begin{aligned}
G\left(\tilde{r}_{2}\right) & =\operatorname{Pr}\left[v_{2}(m)-r_{2} \geq \frac{1}{\lambda} p_{2}(m)\right] \quad \Rightarrow \quad \text { remain } \\
1-G\left(\tilde{r}_{2}\right) & =\operatorname{Pr}\left[v_{2}(m)-r_{2}<\frac{1}{\lambda} p_{2}(m)\right] \quad \Rightarrow \quad \text { move. }
\end{aligned}\right.
$$

The critical value for the contract renewal becomes:

$$
\tilde{r}_{2}=\tilde{r}_{2}(m, \lambda)=v_{2}(m)-\frac{1}{\lambda} p_{2}(m)
$$

We now consider the tenant's payoff. As a freeholder, the tenant is risk neutral and has the discount factor, set at unity. Then, from Eq. (5), the payoff function can be written as:

$$
v_{1}(m)-r_{1}-m+\int_{0}^{\tilde{r}_{2}}\left[v_{2}(m)-r_{2}\right] g\left(r_{2}\right) d r_{2}+\int_{\tilde{r}_{2}}^{\bar{r}_{2}} \frac{1}{\lambda} p_{2}(m) g\left(r_{2}\right) d r_{2}
$$

The first-order condition of Eq. (7) is:

$$
v_{1 m}+G\left(\tilde{r}_{2}\right) v_{2 m}+\left(1-G\left(\tilde{r}_{2}\right)\right) \frac{1}{\lambda} p_{2 m}=1
$$

Define $m_{L}=m_{L}(\lambda)$ as the solution to Eq. (8), where the subscript $L$ refers to leasehold.

Comparing the equilibrium maintenance expenditure levels across the tenure mode captures the effect of land tenure security.

To begin with, consider the case where $\lambda=1$. This case implies that the tenant receives the full return from the dwelling when he or she moves to another dwelling. Comparing Eq. (4) with Eq. (8) shows that $m_{F}=m_{L}$ under $\lambda=1$. The foregoing suggests that the maintenance 
expenditure levels for leasehold and for freehold will be the same. A similar argument has been made by Kanemoto (1990). He has shown that land tenure security leads to optimal investment if subleasing is allowed. This is because, if the leaseholder remains in the dwelling in period 2, he or she receives the benefits of dwelling. If the leaseholder sublet the dwelling, the sublease rent in period 2 would reflect the investment. Thus, the leaseholder fully captures the benefit of the investment. In our model, the sublease rent is equal to the payment of the premises from the landowner to the tenant. Furthermore, comparing Eq. (2) with Eq. (6) shows that $\hat{r}_{2}\left(m_{F}\right)=\tilde{r}_{2}\left(m_{L}\right)$ under $\lambda=1$. Thus $G\left(\hat{r}_{2}^{*}\right)=G\left(\tilde{r}_{2}^{*}\right)$, where $\hat{r}_{2}^{*}=\hat{r}_{2}\left(m_{F}\right)$ and $\tilde{r}_{2}^{*}=\tilde{r}_{2}\left(m_{L}\right)$.

Next consider the case where $\lambda>1 .{ }^{10}$ On the one hand, $\lambda$ has a negative effect on the maintenance expenditure, because $\lambda$ lowers the marginal value of housing when the tenant moves. On the other hand, $\lambda$ has a positive effect on $m$, because $\lambda$ increases the probability of contract renewal for given $m$ (see Eq.(2)).

Thus, if the positive effect outweighs the negative effect, then $m_{F}<m_{L}$. This implies that the tenant overmaintains the dwelling. Furthermore, comparing Eq. (2) with Eq. (6) shows that $\hat{r}_{2}\left(m_{F}\right)<\tilde{r}_{2}\left(m_{L}\right)$. Thus, $G\left(\hat{r}_{2}^{*}\right)<G\left(\tilde{r}_{2}^{*}\right)$. This implies that the tenant is more likely to remain in the premises. Seshimo (2003) has shown that the leaseholder overinvests in the premises to increase the compensation under tenure security. This reduces the opportunity to convert the use of the land. As a result, the tenant is more likely to remain in the premises. In our model, the tenant increases the probability of renewal to capture the benefit of his or her own investment. While our model interpretation is different, we obtain the same result as Seshimo (2003).

If, however, the negative effect outweighs the positive effect, then $m_{F}>m_{L}$. That is, the undermaintenance problem of the leaseholder occurs in this case. This result corresponds to the case of Kanemoto (1990) where subleasing is not allowed. Moreover, if $m_{F}, m_{L}$, and $\lambda$ satisfy the following:

$$
v_{2}\left(m_{F}\right)-p_{2}\left(m_{F}\right)=\hat{r}_{2}\left(m_{F}\right) \gtreqless \tilde{r}_{2}\left(m_{L}\right)=\left[v_{2}\left(m_{L}\right)-\frac{1}{\lambda} p_{2}\left(m_{L}\right)\right] .
$$

Then, $G\left(\hat{r}_{2}^{*}\right) \gtreqless G\left(\tilde{r}_{2}^{*}\right)$. The result shows that there is the case where land tenure security deters

\footnotetext{
${ }^{10}$ Let evaluate Eq. (8) at $m_{L}(\lambda)$. Then, the impact of $\lambda$ on the difference between $m_{F}$ and $m_{L}$ is also found by differentiating Eq. (8) with respect to $\lambda$ and evaluating the derivative at $\lambda=1$.
} 
a tenant from moving in period 2. A case where leaseholders are less likely to remain in the same dwelling than freeholders $\left(G\left(\hat{r}_{2}^{*}\right)>G\left(\tilde{r}_{2}^{*}\right)\right)$ is an intuitive result under $m_{F}>m_{L}$. Leaseholders do not want to dwell in the low-quality housing in period 2. An interesting case is $G\left(\hat{r}_{2}^{*}\right) \leq G\left(\tilde{r}_{2}^{*}\right)$ even under $m_{F}>m_{L}$. The case where $G\left(\hat{r}_{2}\right)=G\left(\tilde{r}_{2}^{*}\right)$ does not imply that the probability of remaining is optimal because of $m_{F}>m_{L}$. As mentioned above, the tenant should renewal the contract to capture the full benefit of his or her own investment. Thus, leaseholders continue to dwell in the same housing units as freeholders even when $m_{F}$ is less than $m_{L}$. An extreme case, in which leaseholders are more likely to remain in the same dwellings than freeholders is where $\left(G\left(\hat{r}_{2}^{*}\right)<G\left(\tilde{r}_{2}^{*}\right)\right) \cdot{ }^{11}$

\section{Empirical Formulation and the Data}

If $\lambda=1$, both maintenance expenditures and the probability of contract renewal become optimal under land tenure security. If $\lambda$ is larger than 1 , however, land tenure security distorts the decisions of leaseholders. The new theoretical results in the preceding section indicate that leaseholders spend less on housing maintenance than freeholders, and are equally (more) likely to remain in the same dwellings as (than) freeholders under land tenure security. Various solutions, however, appear according to the functional forms and the value of $\lambda$. Therefore, the model demonstrates that the impact of land tenure security on housing maintenance and the choice to stay are an empirical questions. In this section, we investigate the empirical evidence on these issues.

The maintenance expenditure functions of freehold and leasehold are respectively controlled by housing and household trait vectors $(\boldsymbol{X})$ as follows:

$$
m_{F}=m_{F}(\boldsymbol{X}), m_{L}=m_{L}(\boldsymbol{X}, \lambda) .
$$

By converting these equations into a single relationship, we may obtain the following maintenance expenditure function:

\footnotetext{
${ }^{11}$ For example, assume that the probability distribution function $g\left(r_{2}\right)$ is uniform on the interval [0,2]. Assume also that $v_{1}(m)=m^{0.5}, p_{2}(m)=0.01 m^{0.5}$, and $v_{2}(m)=100 \times p_{2}(m)=m^{0.5}$, respectively. Then, from Eq. (4) we have, $m_{F}=0.447$. Thus, $G\left(\hat{r}_{2}^{*}\right)=0.331$. Next, we set $\lambda=5$. Then, from Eq. (8) we have, $m_{L}=0.445$. Therefore, $G\left(\tilde{r}_{2}^{*}\right)=0.333$. Accordingly, we have $m_{F}>m_{L}$ and $G\left(\hat{r}_{2}^{*}\right)<G\left(\tilde{r}_{2}^{*}\right)$.
} 


$$
M=M(\boldsymbol{X}, \lambda)
$$

It is difficult to obtain the measurement of tenure security variation $(\lambda)$ from our available data that are shown below. Land tenure security, however, has effect only on leasehold; the difference between freehold and leasehold includes the effect of land tenure security. Thus, we rewrite Eq. (9) as $M=M(\boldsymbol{X}$, LEASEHOLD), where LEASEHOLD is a dummy variable that takes the value of one if the unit is leasehold and zero otherwise. Ultimately, the maintenance expenditure is assumed by the linear regression model:

$$
\text { MAINTENANCE }=\alpha_{1}+\beta_{1} \text { LEASEHOLD }+\boldsymbol{X} \boldsymbol{\gamma}_{1}+\varepsilon_{1}
$$

where MAINTENANCE is a vector of maintenance expenditure, $\alpha_{1}, \beta_{1}$, and $\gamma_{1}$ are coefficients, and $\varepsilon_{1}$ is the error term. We estimate Eq. (10) by means of ordinary least squares (OLS) regression.

We obtain the data for MAINTENANCE from the 1998 Japanese Housing Demand Survey (JHDS). Conducted by the Japanese Ministry of Land, Infrastructure and Transport every five years, the JHDS collects microlevel cross-sectional data on 100,000 households in Japan. The JHDS does ask households to report maintenance expenditures made in the last five years 19931998. We use only those households that respond to this question. That is, only homeowners with nonzero maintenance expenditures are included in the sample. Moreover, we limit the sample to single-family detached owner-occupied housing, because condominiums and apartment buildings have the potential to create a free-rider problem in the sense that owners have an incentive to undermaintain common areas.

We also exclude from the sample any data where the tenancy duration is over 30 years to combine the theoretical model with our empirical model. In Japan, tenants occupy land under a tenancy for a number of years, in general set at 30. Thus, in the sample of over 30 years' duration, a tenant might have renewed the contract at least once. We consider only tenants who have not renewed their contracts, because our theoretical model is a forward-looking model.

Screening the data for complete information on the selected variables produced a sample of 6,115 observations of homeowner expenditures on maintenance. Of these $94.88 \%(5,802$ 
dwellings) are freehold, and 5.12\% (313 dwellings) are leasehold. Table 1 shows that freeholders spend on maintenance 229,600 yen, on average, while leaseholders spend 160,080 yen, on average.

Maintenance expenditure before 1993 is zero even if investment actually took place, because the JHDS is a cross-sectional survey. The JHDS, however, reports the physical condition of housing units. Because maintenance expenditure and the physical condition of housing units might have a positive correlation, the physical condition might be proxy for the maintenance expenditure before 1993. Data on the physical condition of housing units are obtained in the JHDS in the following three categories: repairs not needed, or slight repairs needed, major repairs needed, and dilapidated units beyond repair. As in Gyourko and Linneman (1990), we refer to housing needing no or slight repairs as sound. Then, we define a dummy variable, SOUND, that takes the value of one if the unit is in sound condition and zero if the unit needs major repairs or is dilapidated housing.

Table 1 shows the percentage of sound housing in the sample. Note that $95.93 \%$ of freehold units are in structures reported as sound, while $92.65 \%$ of leasehold units are reported as being in a sound condition.

By defining the dummy variable, SOUND, the following probit specification is estimated:

$$
\mathrm{SOUND}=\alpha_{2}+\beta_{2} \mathrm{LEASEHOLD}+\boldsymbol{X} \gamma_{2}+\varepsilon_{2}
$$

where $\alpha_{2}, \beta_{2}$, and $\gamma_{2}$ are probit coefficients, and $\varepsilon_{2}$ is the error term.

The probability of remaining in the premises for freehold and leasehold becomes:

$$
G\left(\hat{r}_{2}^{*}\right)=G\left[\hat{r}_{2}\left\{m_{F}(\boldsymbol{X})\right\}\right], G\left(\tilde{r}_{2}^{*}\right)=G\left[\tilde{r}_{2}\left\{m_{L}(\boldsymbol{X}, \lambda)\right\}\right],
$$

respectively. By converting these equations into a single relationship, we have:

$$
G(R)=G\{R(\boldsymbol{X}, \lambda)\}
$$

where $R$ is the critical value function. Again, we rewrite it as $R=R(\boldsymbol{X}$, LEASEHOLD). The JHDS does ask householders to report whether or not they will move in the future. Thus, we make REMAIN, a dummy variable that takes the value of one if householders plan to remain 
in the unit and zero otherwise. From Table 1, we find that $93.9 \%$ of freeholders and $94.3 \%$ of leaseholders plan to remain in their units, respectively.

By defining the dummy variable, REMAIN, the following probit specification is estimated:

$$
\operatorname{REMAIN}=\alpha_{3}+\beta_{3} \mathrm{LEASEHOLD}+\boldsymbol{X} \boldsymbol{\gamma}_{3}+\varepsilon_{3},
$$

where $\alpha_{3}, \beta_{3}$, and $\gamma_{3}$ are probit coefficients, and $\varepsilon_{3}$ is the error term.

Table 2 presents descriptive statistics for the variables included in $\boldsymbol{X}$. We use the size of the structure (LOT SIZE, site area measured in units of 10 square meters; and ROOM, the number of rooms), CONSTRUCT. YEAR, the year when the dwelling was built, and the construction material for housing characteristics. Note that if a house was extended or rebuilt, and if the new floor space was more than half of the total floor space of the house following extension or rebuilding, the construction year equates to the extension or rebuilding year in the JHDS. Construction material is classified into the following four categories: wood, buildings whose main frames are made of wood (this is the reference group); steel reinforced concrete (SRC), buildings whose main frames are made of ferroconcrete and steel ferroconcrete; BLOCK, buildings whose outer walls are made of blocks; and OTHERS. We include as homeowner characteristics the total annual income before tax earned by all household members (INCOME), the number of household members (HOUSEHOLD SIZE), the age of the household head (AGE), and the year of relocation to the present dwelling (MOVE-IN YEAR). CONSTRUCT. YEAR (MOVE-IN YEAR) are classified into 14 (11) different categories in the JHDS, from 1 to 14 (1 to 11), i.e., from the oldest to the latest. INCOME is classified into nine different categories in the JHDS, from 1 (the lowest) to 9 (the highest). We add these in ascending order to the explanatory variables in Eqs (10), (11) and (12). Three geographical categories are included, comprising 23 Tokyo wards (TOKYO), 12 major cities outside Tokyo (LARGE CITY), and all other areas (reference). 


\section{Empirical Results}

The results reported in the second column of Table 3 are for the maintenance expenditure function. Before discussing the leasehold dummy variable, we briefly refer to another control variable. ROOM and CONSTRUCT. YEAR coefficients have statistically significant positive values for maintenance expenditures. Households who dwell in a bigger and a newer unit spend more on maintenance. The latter result is contrary to our expectations. However, this may occur because of the definition of the construction year. As discussed, the year of construction in the JHDS can change following an extensive renovation. Coefficients of INCOME, AGE, MOVE-IN YEAR have significant positive coefficients in the maintenance expenditures equation. High-income households spend more on maintenance. Older householders spend more on home maintenance. The shorter time a household has occupied its current dwelling, the more it spends on home maintenance. The variables, TOKYO and LARGE CITY, have significant positive impacts on maintenance expenditures.

Important for our argument is the estimated coefficient on LEASEHOLD. The LEASEHOLD coefficient is a significant negative value for the maintenance expenditures function. That is, leaseholders spend 684,040 yen less than freeholders. From Table 1, freeholders spend on maintenance 229,600 yen, on average. Therefore, maintenance expenditures of leaseholders are about $30 \%(684,040 / 229,600=0.298)$ lower than those of freeholders.

The third column in Table 3 presents the empirical results for SOUND (Eq. (11)). AGE, TOKYO, and LARGE CITY coefficients have different signs from the empirical results for Eq. (10), though they are all insignificant. Again, the LEASEHOLD coefficient is significantly negative. This implies that leasehold premises are less likely to be in sound condition than freehold premises. Thus, the LEASEHOLD coefficient is consistent with the empirical results for the maintenance expenditure function (Eq. (10)).

The fourth column in Table 3 presents the empirical results for REMAIN (Eq. (12)). The LEASEHOLD coefficient is an insignificant positive value. We cannot find the extreme case where leaseholders are more likely to remain in the same dwelling than freeholders. However, we find that the probability of remaining in the dwelling for leaseholders is not different from 
that for freeholders even when undermaintenance problems are present.

\section{Conclusions}

This paper offers a theoretical model and empirical evidence of the effect of land tenure security on maintenance expenditures in Japan. To do this, the paper compares two land tenure modesleasehold and freehold. Because freehold achieves the optimal maintenance level, and because land tenure security has only an effect on leasehold, comparing leasehold with freehold shows us whether maintenance of a leasehold premises is optimal or not under land tenure security. The new theoretical findings are the following combination. First, undermaintenance occurs for leasehold premises because it is difficult for leaseholders to expect a claim equal to the market value of the dwellings even under land tenure security. Secondly, leaseholders are equally (more) likely to remain in the same dwelling to obtain the benefit of their own maintenance expenditures, again because they are not full residual claimants.

Using the 1998 Japanese Housing Demand Survey, the empirical part of the paper indicates that (i) maintenance expenditures of leaseholders are $30 \%$ lower than those of freeholders, (ii) leasehold premises are less likely to be in a sound condition than freehold premises, and (iii) leaseholders are equally likely to stay in the same premises as freeholders. The results of (i) and (ii) suggest that lessees are not full residual claimants although land tenure security laws exist in Japan. Thus, the empirical estimates are consistent with our new theoretical findings.

\section{Acknowledgement}

The authors would like to thank Eddie Chi Man Hui, as well as participants in a Housing Policy Seminar at University of Tokyo and the Asian Real Estate Society International Conference in Macau for their valuable comments. All remaining errors are the sole responsibility of the authors. Part of this paper was written while Shinichiro Iwata was visiting CIRJE, University of Tokyo. He is grateful for its hospitality. This research was supported by MEXT.KAKENHI (15730116 and 17730143). 


\section{References}

Asabere, P. K. 1981. "The Determinants of Land Values in an African City: The Case of Accra, Ghana." Land Economics 57: 385-397.

Asabere, P. K. 2004. "The Pricing of the Emergent Leasehold (Possessory) Estates of Ghana." Real Estate Economics 32: 673-694.

Blandy, S., and Ronbinson, D. 2001. "Reforming Leasehold: Discursive Events and Outcomes, 1984-2000." Journal of Law and Society 28: 384-408.

Brueggeman, W., and Fisher, J. 2006. Real Estate Finance and Investment. New York: Irwin, 13th edition.

Capozza, D. R., and Sick, G. A. 1991. "Valuing Long-Term Leases: The Option to Redevelop." Journal of Real Finance and Economics 4: 209-223.

De Souza, F. A. M. 1998. "Land Tenure Security and Housing Improvements in Recife, Brazil." Habitat International 23: 19-33.

Fry, M. J., and Mak, J. 1984. "Is Land Leasing a Solution to Unaffordable Housing? An Answer from Fee Simple versus Leasehold Property Price Differentials in Hawaii." Economic Inquiry 22: 529-549.

Grenadier, S. R. 2005. "An Equilibrium Analysis of Real Estate Leases." Journal of Business 78: $1173-1213$.

Gyourko, J., and Linneman, P. 1990. "Rent Controls and Rental Housing Quality: A Note on the Effects of New York City's Old Controls." Journal of Urban Economics 27: 398-409.

Hong, Y-H. (1998). "Transaction Costs of Allocating Increased Land Value under Public Leasehold Systems: Hong Kong." Urban Studies 35: 1557-1595.

Janssen, C. T. L. 2003. "Estimating the Effect of Land Leases on Prices of Inner-city Apartment Buildings." Urban Studies 40: 2049-2066. 
Jimenez, E. 1984. "Tenure Security and Urban Squatting." Review of Economics and Statistics 66: $556-567$.

Kanemoto, Y. 1990. "Contract Types in the Property Market." Regional Science and Urban Economics 20: 5-22.

Kanemoto, Y. 1997. "The Housing Question in Japan." Regional Science and Urban Economics 27: 613-641.

La Croix, S. J., Mak, J., and Rose, L. A. 1995. "The Political Economy of Urban Land Reform in Hawaii." Urban Studies 32: 999-1015.

Mayo, S., and Angel, S. 1993. "Housing: Enabling Markets to Work." World Bank Policy Paper, The World Bank, Washington, D.C.

McDonald, I. J. 1969. "The Leasehold System: Towards a Balanced Land Tenure for Urban Development." Urban Studies 6: 179-195.

Miceli, T. J., Sirmans, C. F. and Turnbull, G. K. 2001. "The Property-Contract Boundary: An Economic Analysis of Leases." American Law and Economic Review 3: 165-185.

Payne, G. 2001. "Urban Land Tenure Policy Options: Titles or Rights?" Habitat International 25: 415-429.

Seshimo, H. 2003. "Optimal Tenant Protection." Regional Science and Urban Economics 33: $59-92$.

Sweeney, J. L. 1974. "Housing Unit Maintenance and the Mode of Tenure." Journal of Economic Theory 8: 111-138. 
Table 1

Mean (Frequency) for dependent variables

\begin{tabular}{lcccc}
\hline & Number of Obs. & MAINTENANCE (10,000 yen) & SOUND (\%) & REMAIN (\%) \\
\hline ALL & 6,115 & $226.03[231.15]$ & 95.76 & 93.87 \\
Freehold & 5,802 & $229.60[234.48]$ & 95.93 & 93.85 \\
Leasehold & 313 & $160.08[142.18]$ & 92.65 & 94.25 \\
\hline
\end{tabular}

Square brackets are Std. Dev. 
Table 2

Mean (Frequency/Mode) for independent variables

\begin{tabular}{lcc}
\hline Variable & Mean & Std. Dev. \\
\hline LEASEHOLD (\%) & 5.12 & \\
LOT SIZE $\left(10 \mathrm{~m}^{2}\right)$ & 27.69 & 20.62 \\
ROOM (\#) & 5.96 & 1.50 \\
CONSTRUCT. YEAR & $1976-1990$ & \\
SRC (\%) & 8.55 & \\
BLOCK (\%) & 0.31 & \\
OTHERS (\%) & 3.61 & \\
INCOME (million yen) & $7-10$ & \\
HOUSEHOLD SIZE (\#) & 3.70 & 2.17 \\
AGE & 50.38 & 11.98 \\
MOVE-IN YEAR & $1971-1975$ & \\
TOKYO (\%) & 1.42 & \\
LARGE CITY (\%) & 11.69 & \\
& & \\
Number of Obs. & 6,115 & \\
\hline
\end{tabular}


Table 3

OLS and Probit coefficients

\begin{tabular}{|c|c|c|c|c|c|c|}
\hline \multirow[b]{2}{*}{ Variable } & \multicolumn{2}{|c|}{ MAINTENANCE } & \multicolumn{2}{|c|}{ SOUND } & \multicolumn{2}{|c|}{ REMAIN } \\
\hline & Coef. & Std. Err. & Coef. & Std. Err. & Coef. & Std. Err. \\
\hline INTERCEPT & $-419.969^{* * *}$ & 19.861 & $0.627^{* *}$ & 0.279 & 0.284 & 0.230 \\
\hline LEASEHOLD & $-68.404^{* * *}$ & 10.317 & $-0.261^{* *}$ & 0.122 & 0.044 & 0.120 \\
\hline LOT SIZE & -0.076 & 0.117 & $-0.004^{* *}$ & 0.001 & $0.003^{* *}$ & 0.001 \\
\hline ROOM & $12.265^{* * *}$ & 1.700 & 0.016 & 0.022 & $0.079^{* * *}$ & 0.020 \\
\hline CONSTRUCT. YEAR & $22.011^{* * *}$ & 0.958 & $0.150^{* * *}$ & 0.014 & $0.058^{* * *}$ & 0.011 \\
\hline SRC & $52.620^{* * *}$ & 8.244 & 0.078 & 0.136 & -0.042 & 0.093 \\
\hline BLOCK & -24.017 & 40.823 & -0.318 & 0.447 & -0.159 & 0.404 \\
\hline OTHERS & $60.019^{* * *}$ & 12.238 & 0.011 & 0.213 & -0.010 & 0.144 \\
\hline INCOME & $20.864^{* * *}$ & 1.382 & $0.063^{* * *}$ & 0.018 & $-0.056^{* * *}$ & 0.162 \\
\hline HOUSEHOLD SIZE & 0.412 & 1.109 & 0.0004 & 0.017 & -0.002 & 0.138 \\
\hline AGE & $1.062^{* * *}$ & 0.219 & -0.004 & 0.003 & $0.012^{* * *}$ & 0.003 \\
\hline MOVE-IN YEAR & $23.049^{* * *}$ & 0.973 & -0.015 & 0.014 & -0.003 & 0.012 \\
\hline TOKYO & $176.817^{* * *}$ & 19.419 & -0.334 & 0.233 & -0.239 & 0.189 \\
\hline LARGE CITY & $55.694^{* * *}$ & 7.167 & 0.115 & 0.105 & $-0.128^{*}$ & 0.075 \\
\hline Adj. $R^{2}$ & \multicolumn{2}{|c|}{0.414} & \multirow{2}{*}{\multicolumn{2}{|c|}{0.132}} & \multirow{2}{*}{\multicolumn{2}{|c|}{0.033}} \\
\hline Pseudo $R^{2}$ & & & & & & \\
\hline Number of Obs. & \multicolumn{2}{|c|}{6,115} & \multicolumn{2}{|c|}{6,115} & \multicolumn{2}{|c|}{6,115} \\
\hline
\end{tabular}

*** indicates significant at $1 \%$.

** indicates significant at $5 \%$.

* indicates significant at $10 \%$. 